\title{
PEMBERDAYAAN MASYARAKAT BERBASIS ALUMNI PTKI: ANALISIS ALUMNI PRODI PENGEMBANGAN MASYARAKAT ISLAM UINSU DI KABUPATEN LANGKAT, SUMATERA UTARA
}

\author{
Indira Fatra Deni ${ }^{1 *} \&$ Salamuddin ${ }^{2}$ \\ ${ }^{1}$ Fakultas Ilmu Sosial - Universitas Islam Negeri Sumatera Utara, Medan \\ ${ }^{2}$ Fakultas Dakwah dan Komunikasi - Universitas Islam Negeri Sumatera Utara, Medan
}

\begin{tabular}{|c|c|}
\hline Article History & Abstrak \\
\hline Received : January, 2019 & \multirow{5}{*}{$\begin{array}{l}\text { Tulisan ini ingin melihat bagaimana kampus sebagai miniatur negara } \\
\text { bagi mahasiswa yang menyiapkan kader terbaiknya sebagai penawar } \\
\text { sedingin bagi masyarakat. Alumni sebagai agen perubahan yang } \\
\text { selayaknya mampu menjadi tauladan di tengah kehidupan masyarakat. } \\
\text { Tulisan ini bertujuan untuk mendeskripsikan atau memberikan } \\
\text { gambaran perilaku alumni sebagai motor penggerak perubahan } \\
\text { kebaikan di kalangan masyarakat. Salah satu yang dilakukan alumni } \\
\text { sebagai aktor perubah dengan melakukan pendekatan konsultatif secara } \\
\text { face to face communication, dan edukatif. Yang menjadi tantangan bagi } \\
\text { para alumni dalam melakukan perubahan mental bagi masyarakat yaitu } \\
\text { lembaga alumni yang sangat minim menjadikan mereka sulit untuk } \\
\text { berkoordinasi satu sama lainnya, pemanfaatan fasilitas baik itu } \\
\text { penggunaan teknologi sebagai pendukung kegiatan alumni yang belum } \\
\text { dimanfaatkan secara maksimal. }\end{array}$} \\
\hline Accepted : January, 2019 & \\
\hline Published : February, 2019 & \\
\hline Kata Kunci & \\
\hline $\begin{array}{l}\text { Alumni, kampus, } \\
\text { pembangunan spritual } \\
\text { masyarakat. }\end{array}$ & \\
\hline
\end{tabular}

\section{PENDAHULUAN}

Kampus merupakan miniatur negara bagi seluruh mahasiswa. Penting bagi mahasiswa untuk menghadapi kehidupan masa depannya diawali dari dunia kampus. Oleh karena itu mahasiswa sebagai iron stock bangsa seharusnya memiliki kemampuan akademik yang memumpuni agar mampu menjadi motor penggerak perubahan dalam masyarakat.

Kampus merupakan wadah diskusi bebas nilai yang dijadikan sebagai pusat studi dan pengkajian setiap disiplin ilmu. Tidak dapat dipungkiri bahwa kampus juga melakukan diskusi-diskusi seputar keilmuan dan pengetahuan. Dunia kampus memiliki tugas berat yang harus diemban dan menjadi nilai filosofi dalam melakukan perubahan dimensi dan ruang berpikir masyarakat agar masyarakat dapat memilih dan menjadikan dasar dalam menjalani kehidupan sehari-hari.

Alumni yang telah tamat kampus diharapkan mampu mewarnai dan menjadi patron perubahan masyarakat ke arah yang lebih baik lagi. Seharusnya pula nantinya mampu mewujudkan masyarakat yang madani (civil society). Keberhasilan sebuah lembaga pendidikan dapat dilihat dari partisipasi dan peran alumni di tengah masyarakat dalam mengisi dan menghiasi sebuah perubahan.

Problematika dan dinamika sosial masyarakat saat ini menjadi objek dan lahan bagi para alumni dalam aktualisasi ilmu yang telah didapatkan di kampus. Mulai dari 
persoalan ekonomi, sosial, hukum dan politik. Alumni harus mampu menjadi sandaran masyarakat yang masih butuh dengan kehadirannya. Sebaliknya, alumni bukan menjadi momok bagi masyarakat terhadap persoalan masyarakat. Di dalam jiwa para alumni seharusnya terpatri semangat pembangunan dan pencerahan bagi masyarakatnya. Para peran alumni dianggap amat penting karena berkorelasi dengan kehidupan sosial kemaslahatan umat manusia. Pada perkembangan zaman yang tiada batas, serta yang termasuk di dalamnya masuknya pengaruh globalisasi.

\section{HASIL DAN PEMBAHASAN}

\section{Pembangunan Agama}

Pembangunan sebagai proses perubahan sosial menuju tataran kehidupan masyarakat yang lebih baik. Rogers sebagaimana yang dikutip oleh Rochajat Harun et al secara sederhana menjelaskan pengertian pembangunan adalah perubahan yang berguna menuju suatu sistem sosial dan ekonomi yang diputuskan sebagai kehendak suatu bangsa. Sementara itu menurut Seers, seperti yang di tulis oleh Zulkarimein Nasution, mengistilahkan pembangunan berarti membangkitkan masyarakat di negara-negara sedang berkembang dari keadaan kemiskinan, tingkat melek huruf (literacy rate) yang rendah, pengangguran, dan ketidakadilan sosial.

Dalam pembangunan dibutuhkan komunikasi. Hal inilah yang menyebabkan berdirinya disiplin ilmu komunikasi pembangunan yang bertujuan untuk memajukan pembangunan. Sebagaimana yang dinyatakan oleh Nora C. Quebral dalam Rochajat Harun:

The purpose of development communication is to advance development. Development requires that a mass of people with low rate of literacy and income, and the socio economic attributes that go with it, first of all be informed about and motivated to accept and use a sizeble body of hitherto unfamiliar ideas and skills in very much less time than that process would normally take.

Tujuan pembangunan adalah mencapai pembangunan yang berkelanjutan. Pembangunan menginginkan perubahan pada sekelompok masyarakat yang memiliki tingkat melek huruf dan berpenghasilan rendah, serta tingkat sosial ekonomi yang rendah, semua menjadi terbuka terhadap informasi dan dimotivasi untuk menerima dan menggunakan ide-idenya serta keterampilan yang tidak diketahui dalam waktu singkat dibanding proses yang diambil dalam keadaan normal. Dari pendapat-pendapat di atas dapat ditarik kesimpulan bahwa pembangunan yang akan dilaksanakan membutuhkan sarana. Setiap rencana pembangunan sebaiknya dikomunikasikan terlebih dahulu agar dapat terlaksana dengan baik.

Agama mempunyai kedudukan dan peranan yang sangat penting dan strategis dalam pembangunan nasional. Terutama sebagai landasan spiritual, moral dan etika masyarakat. Agama sebagai sistem nilai seharusnya dipahami dan diamalkan oleh setiap individu, keluarga, masyarakat, serta menjiwai kehidupan berbangsa dan bernegara. Oleh karena itu, pembangunan agama perlu mendapat perhatian lebih besar, baik yang berkaitan deengan penghayatan dan pengamalan agama, pembinaan pendidikan agama, maupun pelayanan kehidupan beragama. 
Sejak era Reformasi, penyusunan kebijakan pembangunan agama pun mulai dibentuk, khususnya mulai dari penyusunan GBHN 1999-2004. Arah kebijakan tersebut bermuara pada upaya memantapkan fungsi, peran dan kedudukan agama sebagai landasan moral, spiritual dan etika, meningkatkan kualitas pendidikan agama, meningkatkan dan memantapkan kerukunan hidup antar umat beragama, serta meningkatkan kemudahan umat beragama dalam menjalankan ibadahnya.

Untuk mengaktualisasikan arah kebijakan yang telah ditetapkan tersebut, maka program-program pembangunan bidang agama adalah sebagai berikut:

a) Program Peningkatan Pelayanan Kehidupan Beragama

Program ini bertujuan untuk: (1) meningkatkan pelayanan dan kemudahan bagi umat beragama dalam melaksanakan ibadah; dan (2) mendorong serta meningkatkan partisipasi masyarakat dalam penyelenggaraan kegiatan pelayanan kehidupan beragama.

Sasaran yang ingin dicapai adalah tertatanya sistem kelembagaan dan manajemen pelayanan serta terpenuhinya sarana dan prasarana keagamaan guna memberi kemudahan bagi umat beragama dalam menjalankan ibadah.

b) Program Peningkatan Pemahaman dan Pengamalan Agama, serta Kerukunan Hidup Umat Beragama

Program ini bertujuan untuk: (1) meningkatkan pemahaman dan pengamalan ajaran agama bagi setiap individu, keluarga, masyarakat, dan penyelenggara negara; (2) memperkuat dasar-dasar kerukunan hidup internal dan antar umat beragama; dan (3) membangun harmoni sosial dan persatuan nasional.

Sasaran yang ingin dicapai adalah terciptanya suasana kehidupan keagamaan yang kondusif bagi upaya pendalaman dan penghayatan agama serta pengamalan ajaran agama, yang mendukung bagi pembinaan kerukunan hidup internal dan antar umat beragama.

\section{c) Program Peningkatan Kualitas Pendidikan Agama}

Pendidikan agama di sekolah umum (TK, SD, SLTP, dan SMU) bertujuan untuk meningkatkan kualitas pemahaman dan pengamalan ajaran agama bagi siswa guna meningkatkan keimanan dan ketakwaan serta pembinaan akhlak mulia dan budi pekerti luhur. Sasaran yang ingin dicapai adalah menurunnya pelanggaran etik dan moral yang dilakukan oleh siswa dan mahasiswa, baik di lingkungan sekolah maupun di masyarakat.

d) Program Pembinaan Lembaga-lembaga Sosial Keagamaan dan Lembaga Pendidikan Tradisional Keagamaan

Program pembinaan lembaga sosial keagamaan dan lembaga pendidikan tradisional keagamaan adalah mencakup pesantren, meunasah, dayah, sekolah minggu, yayasan pendidikan Hindu, dan yayasan pendidikan Budha. Pesantren sebagai lembaga pendidikan agama, secara nyata telah memberikan kontribusi yang amat besar dalam pelayanan pendidikan bagi masyarakat. Pesantren telah membuka 
akses pendidikan bagi masyarakat miskin di pedesaan. Selain memberikan pendidikan agama, pesantren juga memberikan bekal keterampilan praktis kepada para santri/siswa seperti pertanian, peternakan, perbengkelan, jahit-menjahit, bahkan operator komputer. Pesantren sebagai lembaga pendidikan memiliki riwayat sejarah yang sangat panjang dan menjadi salah satu varian dalam keanekaragaman jenis pendidikan yang ada, tetapi belum sepenuhnya menjadi bagian dari sistem pendidikan nasional.

\section{Alumni dan Peningkatan Pengamalan Keagamaan Masyarakat}

Alumni memiliki peran dan fungsi dalam peningkatan pengamalan agama. Beberapa persoalan yang didapat dari para alumni adalah: setelah tamat para alumni miskomunikasi dengan lainnya, kehilangan lembaga komunikasi yang terstruktur atau lebih dikenal dengan lembaga ikatan alumni, disebabkan oleh mementingkan kehidupan personal tanpa melihat dan memanfaatkan jaringan para alumni untuk bersilaturahmi lintas generasi. Masyarakat akan lebih mudah berinteraksi dengan alumni ketika mereka mengetahui identitasnya.

Alumni secara persuasif dan terstruktur melakukan kontribusi peningkatan pengamalan keagamaan masyarakat dengan cara berbaur langsung dengan masyarakat dan bersosialita, sehingga tanpa disadari oleh alumni yang mereka lakukan adalah langsung berhubungan dengan masyarakat setempat sekalipun banyak yang tidak memiliki jadwal terukur. Dengan memberikan bantuan materi dan inmateri kepada masyarakat di tempat mereka bertempat tinggal. Memberikan nasehat-nasehat kepada remaja, anak dan masyarakat umum melalui ceramah, khotbah dan pertemuan lainnya.

Seluruh lapisan masyarakat menjadi sasaran pengabdiannya. Karena seluruh alumni terlibat dalam melakukan beberapa kegiatan sosial masyarakat. Namun, keterlibatan itu diklaim sebagai proses pembinaan yang tidak tersusun secara rapi dalam program, misalkan para alumni masuk pengajian dan perwiridan rutin sebagai bentuk perbuatan yang mencontohkan kepada masyarakat kalau hadir dalam perwiridan merupakan aplikasi peningkatan keagamaan selain melakukan kegiatan wajib seperti shalat, puassa dan zakat. Menjalin silaturahmi dalam bentuk perwiridan merupakan kegiatan yang real dalam hablum minannas. Alumni seharusnya memanfaatkan aktivitas seperti peringatan hari besar Islam seperti Isra' Mi'raj dan Maulid sebagai momentum perbaikan pengamalan keagamaan. Dengan menghadirkan penceramah ataupun guru ngaji, peran alumni masuk sebagai kepanitiaan dan membantu masyarakat untuk menyukseskan kegiatan tersebut.

\section{Strategi Alumni dalam Peningkatan Pengamalan Keagamaan Masyarakat}

Dalam rangka peningkatan pengamalan keagamaan masyarakat di tempat alumni berada kegiatan klasik seperti masyarakat pada umumnya merupakan strategi yang selalu dilakukan para alumni seperti keterlibatan mereka di tengah kegiatan sosial masyarakat, dialog langsung dengan tatap muka, interaksi sosial yang secara rutinitas dilakukan alumni terhadap masyarakat umum. Jarang para alumni melakukannya dengan memanfaatkan teknologi. Hasilnya mereka melakukan pendekatan persuasif dengan masuk langsung aktif dalam kegiatan masyarakat adalah cara yang paling tepat karena masyarakat yang masih minim dengan informasi dan perubahan zaman. Materi 
dalam interaksi juga masih seputar halal dan haramnya sesuatu perbuatan dilakukan, tidak melihat bahwa masih banyak tema lainnya yang lebih mendorong kemajuan dan peningkatan pengamalan agama, seperti manfaat ibadah yang secara praktis didapat oleh manusia. Dukungan masyarakat terhadap alumni yang melakukan kegiatan kerohanian yang berdampak pada peningkatan pengamalan keagamaan masyarakat setempat.

\section{Hambatan Alumni dalam Peningkatan Pengamalan Keagamaan Masyarakat}

Peningkatan pengamalan keagamaan yang dilakukan oleh para alumni pada dasarnya memiliki hambatan, baik yang sangat signifikan mempengaruhi keberhasilan kontribusi alumni maupun hanya sebatas hambatan kecil yang mampu dihadapi oleh para alumni. Para alumni memiliki sedikit hambatan dalam melakukan interaksi dengan masyarakat. Hambatan yang dihadapi para alumni sangat bervariatif seperti waktu yang selalu menjadi penghalang alumni yang selalu ingin berinteraksi kepada masyarakat setempat namun karena disibukkan oleh aktivitas pekerjaan dan keluarga yang menyita waktu para alumni untuk bersosialisasi secara rutin. Interaksi terhadap masyarakat setempat merupakan sisa waktu yang telah tersita oleh pekerjaan mereka. Kemudian fasilitas yang menjadi hambatan kegiatan para alumni seperti alat-alat bantu komputer, jaringan WiFi sebagai fasilitas terpenting alumni untuk mengakses informasi dan kondisi terkini terkait kehidupan masyarakat yang semakin maju.

\section{PENUTUP}

Alumni dalam Peningkatan Pengamalan Keagamaan Masyarakat memberikan informasi-informasi yang terkait dengan keagamaan kemudian kegiatan konsultatif. Kemudian peran yang besifat edukatif dilakukan dalam memberikan pengetahuan agama kepada masyarakat, memberikan pemahaman tentang Al Qur'an, memberikan bimbingan dan pelatihan serta menjadi teladan yang baik bagi masyarakat.

Hambatan Alumni dalam Peningkatan Pengamalan Keagamaan Masyarakat diantaranya yaitu adanya jarak antara para alumni yang sulit dijangkau untuk berkordinasi, fasilitas yang kurang memadai sehingga akses informasi dan pengetahuan yang terkadang tidak tersaring dengan baik mendatangkan dampak yang negatif bagi masyarakat. Selain hambatan yang diperoleh dari masyarakat, hambatan tersebut juga muncul dari pribadi alumni sendiri. Seperti pemanfaatan fasilitas sebagai pendukung kegiatan alumni dalam peningkatan pengamalan keagamaan.

\section{REFERENSI}

Arifin, Anwar. (2011). Dakwah Kontemporer: Sebuah Studi Komunikasi. Yogyakarta: Graha Ilmu.

Arikunto, Suharsimi. (2006). Prosudur Tulisan: Suatu Pendekatan Praktik. Jakarta: Rineka Cipta.

Aw, Suranto. (2010). Komunikasi Sosial Budaya. Yogyakarta: Graha Ilmu.

Bodgan, R.C dan S.K Biklen. (1982). Qualitative Research for Education. Boston: Allyn and Bacon. Inc. 
Bungin, Burhan. (2012). Analisis Data Tulisan Kualitatif. Jakarta: PT. RajaGrafindo Persada.

Bungin, Burhan. (2010). Tulisan Kualitatif. Jakarta: Prenada Media Group.

Bungin, Burhan. (2008). Sosiologi Komunikasi. Jakarta: Kencana Prenada Media Group.

Cangara, Hafied. (2009). Komunikasi Politik: Konsep, Teori dan Strategi. Jakarta: Rajawali Pers.

Daryanto. (2011). Ilmu Komunikasi. Bandung: PT. Sarana Tutorial Nurani Sejahtera.

Departemen Agama RI. (2011). Al-Qur'an dan Terjemahnya. Bandung: Gema Risalah Pers.

Dilla, S Umadi. (2007). Komunikasi Pembangunan: Pendekatan Terpadu. Bandung: Simbiosa Rekatama Media.

Kholil, Syukur. (2009). Bimbingan Konseling: Dalam Perspektif Islam. Bandung: Cita Pustaka Media Perintis.

Kholil, Syukur. (2005). Metodologi Tulisan Komunikasi. Bandung: Remaja Rosdakarya.

Lincoln, Denzin N.K. (1994). Hanbook of Qualitative Research. New Delhi: Sage Publication.

Moleong, Lexy J. (1995). Metode Tulisan Kualitatif. Bandung: Remaja Rosdakarya.

Muhadjir, Noeng. (1990). Metodologi Tulisan Kualitatif. Jakarta: Gramedia.

Poerwadarminta, W.J.S. (2003). Kamus Umum Bahasa Indonesia. Jakarta: Balai Pustaka.

Rahmat, Jalaluddin. (1996). Islam Aktual. Bandung: Mizan.

Kementerian Agama RI Direktorat Jendral Bimbingan Masyarakat Islam Direktorat Penerangan Agama Islam. Buku Penunjang Tugas Penyuluh Agama, 2007

Kementerian Agama RI Direktorat Jendral Bimbingan Masyarakat Islam Direktorat Penerangan Agama Islam. Panduan Tugas penyuluh Agama Islam Utama, 2004

Muhammad Nuh Hasibuan dalam "Peran Penyuluh Agama dalam Pemberdayaan Majelis Ta’lim Kaum Ibu dalam Meningkatkan Pemahaman dan Pengamalan Agama" /www.kemenag.go.id diunduh pada tanggal 10 April 2013.

Undang-Undang No. 25 tahun 2000 tentang Program Pembangunan Nasional (Propenas) Tahun 2000-2004. 